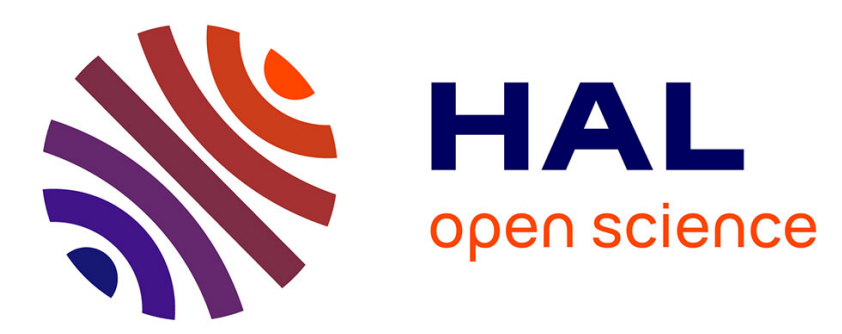

\title{
Testing environmental regulations, green innovation and social distribution as determinants of environmental sustainability: a case of ASEAN region
}

Ichsan Anwary, Yahya Ahmad Zein

\section{- To cite this version:}

Ichsan Anwary, Yahya Ahmad Zein. Testing environmental regulations, green innovation and social distribution as determinants of environmental sustainability: a case of ASEAN region. Journal of Security and Sustainability Issues, 2020, 10 (October), pp.253 - 265. 10.9770/jssi.2020.10.oct(19) . hal-03121036

\section{HAL Id: hal-03121036 \\ https://hal.science/hal-03121036}

Submitted on 26 Jan 2021

HAL is a multi-disciplinary open access archive for the deposit and dissemination of scientific research documents, whether they are published or not. The documents may come from teaching and research institutions in France or abroad, or from public or private research centers.
L'archive ouverte pluridisciplinaire HAL, est destinée au dépôt et à la diffusion de documents scientifiques de niveau recherche, publiés ou non, émanant des établissements d'enseignement et de recherche français ou étrangers, des laboratoires publics ou privés. 
JOURNAL OF SECURITY AND SUSTAINABILITY ISSUES

ISSN 2029-7017/ISSN 2029-7025 (online)

2020 Volume 10 Number (October)

http://doi.org/10.9770/jssi.2020.10.Oct(19)

Scopus

\title{
TESTING ENVIRONMENTAL REGULATIONS, GREEN INNOVATION AND SOCIAL DISTRIBUTION AS DETERMINANTS OF ENVIRONMENTAL SUSTAINABILITY: A CASE OF ASEAN REGION
}

\author{
Ichsan Anwary ${ }^{1 *}$, Yahya Ahmad Zein ${ }^{2}$ \\ ${ }^{I}$ Department of Law, Universitas Lambung Mangkurat, Jl. H. Hasan Basry, Banjarmasin, Indonesia \\ ${ }^{2}$ Department of Law, Universitas Borneo Tarakan, Jl. Amal Lama No. 1, Tarakan, Indonesia \\ E-mail: ${ }^{*}$ ichsan.anwary@ulm.ac.id (Corresponding author)
}

Received 10 November 2019; 29 June 2020; published 30 October 2020

\begin{abstract}
Regulations and policies regarding environment and green and environment friendly innovations play an important role in the reduction in pollution and to make the environment clean to live a better life. In this regard, people play a critical part by following these policies and regulations and by promoting the green innovations. The current study has been designed with the aim to find out and investigate the impact of environmental regulations, green innovation, and social distribution on the environmental sustainability of ASEAN countries. Therefore, the data for the study has been gathered from ASEAN countries covering the period of 29 years. The accuracy of the results obtained by the analysis of data collection has been ensured by the collection of data from World Bank Development Indicators and Global Economy. Various tests and techniques have been applied on the collected data such as panel unit root test, panel cointegration test, FMOLS coefficient estimation and Granger Casualty test. The result obtained by the analysis indicated that all the independent (environmental regulations, green innovation, and social distribution) and control variables (per capita income and human development) have significant impact on environmental sustainability. Moreover, the researcher also found the casual relationships between various variables of the study.
\end{abstract}

Keywords: Environmental Regulations; Green Innovation; Social Distribution; Environmental Sustainability; ASEAN Countries

Reference to this paper should be made as follows: Anwary, I., Zein, Y.A. 2020. Testing environmental regulations, green innovation and social distribution as determinants of environmental sustainability: a case of ASEAN region. Journal of Security and Sustainability Issues, 10(Oct), 253-265. https://doi.org/10.9770/jssi.2020.10.Oct(19)

Jel Codes: O1, 053

\section{Introduction}

Environmental sustainability is a concept that means to be more conscious towards the environment (Rosen, 2018; van Huis \& Oonincx, 2017). In the current era, the majority of developing and developed nations worked on establishing a sustainable environment within their states so that the climate change and global warming based environmental issues can be resolved (Baland, Bardhan, \& Bowles, 2018; Tvaronavičienė, \& Ślusarczyk, 2019; Eddelani et al., 2019; Moumen et al., 2019; Prasetyo, \& Kistanti, 2020; Hernández de Velazco, Ravina Ripoll, \& Chumaceiro Hernandez, 2020; Nuryakin, \& Maryati, 2020; Igaliyeva, Niyazbekova, Serikova, Kenzhegaliyeva, Mussirov, Zueva, Tyurina, \& Maisigova 2020; Mikhaylov, Moiseev, Aleshin, \& Burkhardt, 2020; Khan, Maqbool, Haleem, \& Khan Mohd, 2020; Issock Issock Paul, Roberts-Lombard, \& Mpinganjira, 2020).

In the ASEAN states, more than 600 million people are living in urban areas and its figure is continuously increasing, so there is a major need to ponder on the environmental issues (Kheng-Lian, Robinson, \& Lin-Heng, 2016). According to the report of ASEAN Progress Towards Sustainable Development Goals, the IMF plays a significant role to give support to the ASEAN states in this challenging environmental situation (Sukcharoensin, 2018; Yonn, 2017). There are ten major ASEAN countries (Malaysia, Indonesia, Thailand, Singapore, Myanmar, Laos, Cambodia, Burnie, Philippines and Vietnam) who effectively achieving sustainable development within this region. Their strong income and stable consumption growth directly reduced poverty, improve education and 
health outcomes, and result in great inclusion within their states. These nations are collectively worked to obtain sustainable environmental growth. Their tax revenue based outcomes in the last three decades are given below (Figure 1)

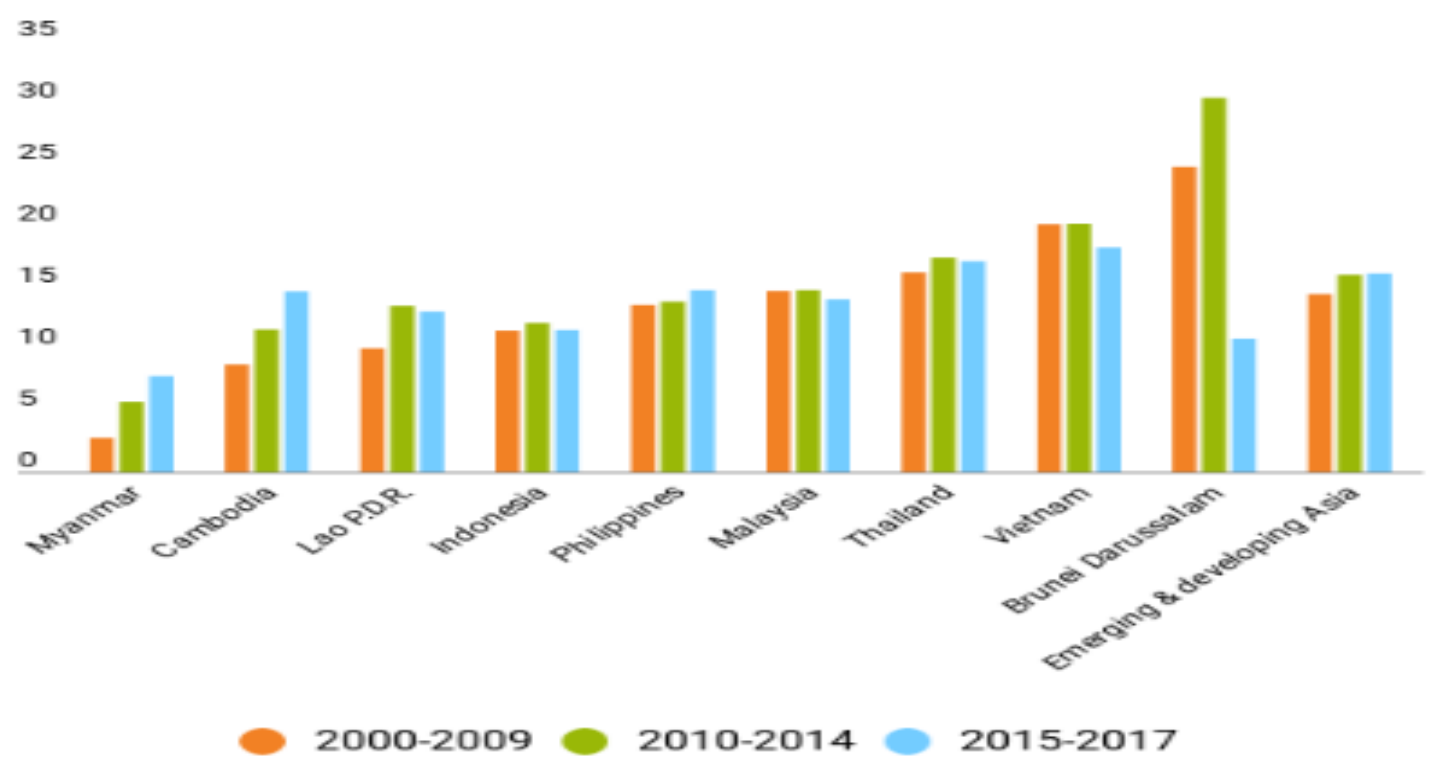

Figure 1: Environmental Tax Revenue within most developing ASEAN countries

The above figure depicts that Brunei Darussalam is that advanced developing state whose management faced great fluctuation in its GDP outcomes (X. Liu, Zhang, \& Bae, 2017). Well, Thailand, Malaysia, and other related energy states are more capable to develop their environmental strategic approaches. In addition, there are major green investment opportunities for infrastructural development within the ASEAN states (Anbumozhi, 2017). Their statistics are shown in the following table 1.

Table 1: Green Investment Opportunities within ASEAN states

\begin{tabular}{ll}
\hline ASEAN states & Percentage of Green Investment Opportunities \\
\hline Thailand & $12 \%$ \\
\hline Singapore & $2 \%$ \\
\hline Philippines & $15 \%$ \\
\hline Myanmar & $7 \%$ \\
\hline Malaysia & $9 \%$ \\
\hline Vietnam & $16 \%$ \\
\hline Cambodia & $3 \%$ \\
\hline Indonesia & $36 \%$
\end{tabular}

The problem statement of this paper is to critically evaluate the significance of environmental regulations, green innovation, and social distribution on the development of environmental sustainability within the developing ASEAN states. This aim based strategic approach will help to make a strategic decision regarding which dimension cause a major impact on sustainable environmental development in the global warming situation.

This study is informative and challenging which directly overcome all the deficiencies made by the previous scholars in their related studies. Like according to previous literature, the majority of the researches has been made on the environmental sustainability factor, but neither of them specifically tests the major determinants of 


\section{JOURNAL OF SECURITY AND SUSTAINABILITY ISSUES}

ISSN 2029-7017/ISSN 2029-7025 (online)

2020 Volume 10 Number (October)

http://doi.org/10.9770/jssi.2020.10.Oct(19)

environmental sustainability e.g. environmental regulations, green innovation and social distribution, in the ASEAN region perspective. Majority of the researchers critically evaluate this sustainability concept with globalization, foreign direct investment, green innovation efficiency and other business operation perspective (Feng, Zeng, \& Ming, 2018; Piyathanavong, Garza-Reyes, Kumar, Maldonado-Guzmán, \& Mangla, 2019; Suki, Sharif, Afshan, \& Suki, 2020; Iqbal, et al., 2020), but nobody majorly worked on deriving the major sustainability provoking determinants within the developing Southeast Asian countries. In this paper, the major objective is;

- To investigate the impact of environmental regulations on environmental sustainability within the ASEAN region.

- To investigate the impact of green innovation on environmental sustainability within the ASEAN region.

- To investigate the impact of social distribution on environmental sustainability within the ASEAN region.

- To identify the major determinant to majorly enhance environmental sustainability.

This study is an informative approach in front of the environmentalist, policymakers, state's authority, and the business community to consider the importance of the tested determinants in sustainable environmental development. Like the environmental regulation and social-based strategic variables will help, the related field environmentalist and the nation's government to develop such decisions and regulations that directly reduced the carbon emission within the state and enhance their sustainable environment by promoting natural resources. In addition, such information will help the local natives within the ASEAN region to consider their social responsibilities towards the healthy environment development that directly affect their socio-economic development. In addition, the green innovation based entrepreneurial approach and its implication on the sustainable environment concept within this research will motivate the business community, analysts and management to develop such operating and marketing activities that fulfill their environmental need and gain their customer satisfaction and positive word of mouth for sustainable growth.

After considering the problem statement, research objectives, research question, its justification and significance within this chapter one, introduction, it's time to work on section 2 named as the literature review. In this portion, all the previous scholars' work will be critically considered and evaluated to propose a relevant hypothesis associated with these research objectives. After this, there will be a third section, research methodology, where the data collection, sampling, and the applied statistical tests clearly discussed. This section is considered as an important research portion in which all the technical information regarding the variables testing and the participants' demographic descriptions are considered (Ghauri, Grønhaug, \& Strange, 2020; Kalton, 2020; Kanwal, et al., 2020). In section 4 of analysis interpretation, all the SPSS test based values evaluation will be made to inspect that either the outcome of the results is significant or not in order to justify or nullify the hypothesis. Last, but not the least, discussion and conclusion based major heading cover all the consequences of the hypothesis by considering the related scholars' work to enhance the authenticity of this paper (Valencia et al., 2020). In addition to concluding all the research's outcomes, its future implications and limitations will also be explained that enhanced the upcoming scholar's opportunity to utilize this paper information.

\section{Literature Review}

\subsection{Environmental Sustainability Theory}

The sustainability theory is majorly based on promising and integrating the social response towards the cultural and environmental issues within a state (Font, Garay, \& Jones, 2016; Freudenreich, Lüdeke-Freund, \& Schaltegger, 2019). It has three major models like the first one is an economic model which directly based on sustaining the natural and financial capital, the second one is an ecological model that looks towards the ecological integrity and biological diversity, and the third one is a political model which based on the social system in order to realize the human dignity concept (Stern, 2018). This theoretical concept is a helpful approach 


\section{JOURNAL OF SECURITY AND SUSTAINABILITY ISSUES}

ISSN 2029-7017/ISSN 2029-7025 (online)

2020 Volume 10 Number (October)

http://doi.org/10.9770/jssi.2020.10.Oct(19)

in front of the business community and the state's administration to consider the environmental sustainability factor in their strategic decision-making process and enhanced their profit margin (Hummel \& Schlick, 2016). Silvana Ligia Vincenzi with others in their Cleaner Production Journal majorly worked on examining the environmental sustainability perception in terms of items response theory. The sustainability perception-based measurement scale is used to develop local environmental governance to upgrade the environment and social education with the alternatives goals to raise a local residents' perception (Vincenzi et al., 2018). In addition to this, other researchers majorly worked on exploring the importance of this theoretical approach towards sustainable environmental growth within a developing and developed state. Others majorly designed the sensemaking support system based effective principles in the economic transformation towards environmental sustainability within a state (Dinica, 2018; Seidel, Chandra Kruse, Székely, Gau, \& Stieger, 2018).

\subsection{Environmental Regulations and Environmental Sustainability}

In order to explore the relationship between the environmental regulations and its sustainability factor, many researches have been made by environmentalist and analyzers where they stated that in the current era, the environment-related productive regulation and its innovation cause a significant impact of the efficient sustainable firm's performance because such strategic approach gives flexibility in their operating activities (Ramanathan, He, Black, Ghobadian, \& Gallear, 2017). Also, the trade liberalization based strategic activities within a state play a significant role to develop a sustainable environment (Mahrinasari, Haseeb, \& Ammar, 2019). In 2017, Piera, Roberto and Emilio majorly stated that green initiatives and its related regulations within a state caused a significant impact on sustainable development within a state. According to the researchers, the green IT system directly boosts the sustainability concept within a state (Centobelli, Cerchione, \& Esposito, 2017; Niesten, Jolink, de Sousa Jabbour, Chappin, \& Lozano, 2017). According to these scholars, there is a great influence of governance and institution on the environmental regulations that is why those developing nations who having weak administration and policymaking departments are facing major environmental issues. This shows that environmental regulation regarding technology and other business-oriented activities caused a direct influence on a healthy environment (Abdelzaher \& Abdelzaher, 2017; Dalle et al. 2020). Hence, after critically evaluate the previous research, the following hypothesis will be generated.

\section{H1: There is a significant relationship between Environmental Regulations and Environmental Sustainability}

\subsection{Green Innovation and Environmental Sustainability}

Like the previous ones, the green innovation within the business activities directly impact on boosting the concept of environmental sustainability within a state. According to the researchers, if the business marketing department becomes successful in developing the green innovation within their consumer market by generating their needs, then more efficient outcomes will be made (Song \& Yu, 2018; Tang, Walsh, Lerner, Fitza, \& Li, 2018). In most scholars stated that such innovation in the business field caused a direct impact on the efficient sustainability concept within a state and boost the ecological footprints within a state. According to them, the advanced technological development within a state caused an excessive greenhouse gas emission and this global warming issue can be resolved by enhancing this green innovation-based awareness concept (Gliedt, Hoicka, \& Jackson, 2018; Li, Huang, Ren, Chen, \& Ning, 2018; Luo \& Wu, 2020). In 2016, Dayuan Min, Shenggang, Xiaohong and Lutao majorly concluded that there is a major need to reduce the carbon emission based climate change situation by making environmental legitimacy and green innovation based strategic growth (Li et al., 2018; Mei, et al., 2020). According to them, an internal formal mechanism-based green innovator plays a significant role to mitigate the carbon dioxide emission oriented problematic situation within a state. In the current era, majority of the companies utilize both formal and informal mechanism i.e. internal green process innovation and external environmental legitimacy, to ensure sustainability by disclosing the carbon information. Therefore, the following hypothesis will be suggested from the previous literature. 
JOURNAL OF SECURITY AND SUSTAINABILITY ISSUES

ISSN 2029-7017/ISSN 2029-7025 (online)

2020 Volume 10 Number (October)

http://doi.org/10.9770/jssi.2020.10.Oct(19)

\section{H2: There is a significant relationship between Green Innovation and Environmental Sustainability}

\subsection{Social Distribution and Environmental Sustainability}

Social distribution is such a marketing-based commune practice that cause a major influence on circulating the information regarding environmental sustainability through networking, social media platforms, word of mouth, etc. In 2017, Armin Scheidal with others stated that there is a direct link between a pattern of social metabolism, rise of environmental justice distribution conflict, the emergence of the ecological distribution and the potential contributions for the sustainable transition that caused a direct impact on sustainable environment development (Scheidel, Temper, Demaria, \& Martínez-Alier, 2018). Effective communication plays a significant role to boost an environmental concept. The Global Environmental Justice Atlas based ecological distribution conflicts were considered by Leah Temper and others (2018) where they stated that ecological distribution conflict caused a major impact on the sustainability factor and developed such environmental issues that directly hit the healthy climate and many other environmental issues (Temper, Demaria, Scheidel, Del Bene, \& Martinez-Alier, 2018). In the sustainability science-based informative journal, the related scholars stated that there are some trends in the social metabolism and the environmental conflict that cause a drastic change in Bolivia, Colombia, Peru and Ecuador countries (Grabara, Hussain \& Szajt, 2020). According to them, biomass, fossil fuels, hydropower, and mining are the major conflicting sectors within a state (Pérez-Rincón, Vargas-Morales, \& Crespo-Marín, 2018). In the current era, there is a need to develop efficient social distribution concepts towards ecosystems that result in sustainable environmental sustainability factors. In the ecosystem service-based journal, the scholars refocused the ecosystem towards sustainability where their major aim is to make justice within the ecological limits for the long run. In their study, they majorly emphasized inter-intergenerational, interspecies and procedural distribution, and concluded that efficiency, sufficiency and persistence are the major strategies to control the ecological limits (Schröter et al., 2017). The similar statistical research outcomes made by the scholars where they justified that efficient social distribution within a developing state causes an effective development of sustainable environment and secure the state's future (Clayton, Kals, \& Feygina, 2016; Saunila, Ukko, \& Rantala, 2018; Temper et al., 2018). So, the following hypothesis will be proposed from previous researches;

\section{H3: There is a significant relationship between Social Distribution and Environmental Sustainability}

\section{Methodology}

\subsection{Data}

This section contains detailed information about the data collection method adopted by the researcher and the techniques and tools that have been used to analyze the collected data appropriately. First of all, the data collection process will be discussed. It is quite clear that the objective of the study directly impacts the data collection procedure and thus based on the objective of this particular study i.e. to explore the effect of environmental regulations, green innovation and social distribution on the environmental sustainability of ASEAN countries, the data for the study has been gathered from ASEAN countries covering the time period of 29 years. The accuracy of the results obtained by the analysis of data collection has been ensured by the collection of data from World Bank Development Indicators and Global Economy, the most reliable data sources as per the data required for this study.

\subsection{Model Specification}

In context of model specification, the measurement units of the variables of the study must be made clear before generating the regression equation. In this regard, the dependent variable, environmental sustainability has been measured by using an index named as environmental sustainability index and has been denoted by ENS. The first independent variable of the study, environmental regulations have been measured through an index named 
environmental protection index and has been represented by ENR. The next independent variable, green innovation has been measured through the revenues obtained from the sales of green products and has been denoted through GRI. The last independent variable, social distribution has been measured through social capital index and represented by SOD. In addition to these variables, two control variables have also been taken into consideration i.e. per capita income and human development. Per capita income has been measured through US dollars and denoted by PCI while the human development has been measured through the human development index and represented by HUD. In this way, the following regression model can be generated;

$$
\mathrm{ENS}_{\mathrm{it}}=\alpha+\beta_{1} \mathrm{ENR}_{\mathrm{it}}+\beta_{2} \mathrm{GRI}_{\mathrm{it}}+\beta_{3} \mathrm{SOD}_{\mathrm{it}}+\beta_{4} \mathrm{PCI}_{\mathrm{it}}+\beta_{5} \mathrm{HUD}_{\mathrm{it}}+\varepsilon_{\mathrm{it}}
$$

Here, ENS represents environmental sustainability, ENR shows environmental regulations, GRI denotes green innovation, SOD represents social distribution, PCI shows per capita income, HUD denotes human development and $\mathrm{e}_{\mathrm{it}}$ is the error term.

\subsection{Estimation Procedure}

\subsubsection{Panel Unit Root Test}

As the first step, the researcher intended to find out the order of integration of the variables of the study and the stationarity of the collected data and for this purpose, the panel unit test was applied by the researcher (Levin, Lin, \& Chu, 2002). Although, various tests have been used in this regard but the researcher has preferred LLC test in the current study with null and alternate hypothesis. The null hypothesis involves the non stationary condition of the collected data while alternate hypothesis involves the stationary condition of the collected data. Based on these hypotheses, the results of panel unit root test are interpreted (Levin \& Lin, 1993). The following model has been used for panel unit root test;

$\Delta y_{i, t}=a_{i}+\rho y_{i, t}-1+\sum_{J=1}^{p i} a_{J} \Delta y_{i, t-J}+\varepsilon_{i, t}$

\subsubsection{Panel Cointegration Test}

In the next step, the researcher had intended to find out whether there is any cointegrated relationship present between the variables of the study or not and for this purpose, the panel cointegration test has been applied in the study. Two different statistics i.e. homogenous panel or within dimension and heterogeneous group or between dimension have been considered in the test (Pedroni, 1999). Moreover, the results are interpreted on the basis of rejection of null hypothesis which refers to the absence of cointegrated relationships between the variables (Pedroni, 2001). In this regard, the following model has been used in the study,

$y_{i, t}=\alpha_{i}+\delta_{i, t}+\beta_{1} X_{1, i, t}+\beta_{2} X_{2, i, t}+\cdots+\beta_{n} X_{n, i, t}+\varepsilon_{i, t}$

\subsubsection{Estimating the Coefficient with FMOLS}

In the next step of the estimation procedure, the researcher wanted to find out the most important aspect of the study i.e. the impact of independent and control variables on the dependent variable and for this purpose, the FMOLS coefficient estimation test has been applied in the study. It has been derived from ordinary least square OLS to resolve the issues of serial correlation and endogeneity which might possibly have been caused by the cointegration among the variables (Pedroni, 2000). The following model has been considered for this test;

$\widehat{\beta}_{\mathrm{FM}}=\left(\sum_{\mathrm{i}=1}^{\mathrm{N}} \sum_{\mathrm{t}=1}^{\mathrm{T}}\left(\mathrm{x}_{\mathrm{i}, \mathrm{t}}-\overline{\mathrm{X}}_{\mathrm{i}}\right)^{2}\right)^{-1} \sum_{\mathrm{i}=1}^{\mathrm{N}}\left(\sum_{\mathrm{t}=1}^{\mathrm{T}}\left(\mathrm{x}_{\mathrm{i}, \mathrm{t}}-\overline{\mathrm{x}}_{\mathrm{i}}\right) \widehat{\mathrm{ENS}}_{\mathrm{i}, \mathrm{t}}-\mathrm{T} \hat{\delta}_{\mathrm{eu}}\right)$

In this equation, $\widehat{\mathrm{ENS}}_{\mathrm{i}, \mathrm{t}}$ is the transformed variable of ENS due to endogeneity while $\widehat{\delta}_{\mathrm{zu}}$ represents the serial correlation correction. 
JOURNAL OF SECURITY AND SUSTAINABILITY ISSUES

ISSN 2029-7017/ISSN 2029-7025 (online)

2020 Volume 10 Number (October)

http://doi.org/10.9770/jssi.2020.10.Oct(19)

\subsubsection{Panel Granger Casualty Test}

In the last, the researcher intended to find out if there are any casual relationships between the variables or not and for this purpose, Granger casualty test has been used in the study. The presence of casual relationships has high chances because of the cointegration among variables. So Dumitrescu and Hurlin Granger Casualty test based on null hypothesis of no casualty and alternate hypothesis of casualty has been used in the study (Dumitrescu \& Hurlin, 2012).

\section{Results and Analysis}

\subsection{Results of Panel Unit Root Test}

The first test applied for the exploration of order of integration of the variables i.e. IPS panel unit test has its results as shown in the table 1 . The intercept and intercept plus trend results for both level and first difference series have been reported separately in detailed way. Let us discuss both of them one by one. As far as the level series is concerned, it is clear from the table that three variables in both intercept and intercept plus trend have rejected the null hypothesis and the remaining four have accepted it. The variables that have rejected the null hypothesis include environmental regulations, social distribution and per capita income. Contrary to the level series, in the first difference series, the null hypothesis has been rejected by all the variables of the study both for intercept and intercept plus trend. The end result or nut shell is that the data is non stationary at level series but it has become stationary at first difference series. The detailed results along with the relative values can be viewed in the table 2 .

Table 2: Panel Unit Root Test - Im, Pesaran and Shin (IPS)

\begin{tabular}{|c|c|c|c|c|}
\hline Variable & Level & & $1^{\text {st }}$ difference & \\
\hline & Intercept & Intercept + Trend & Intercept & Intercept + Trend \\
\hline ENS & -2.2940 & -2.2883 & $-6.2949 * *$ & $-6.6661 * *$ \\
\hline ENR & $-3.1274 *$ & $-3.1844 *$ & $-7.5204 * *$ & $-7.5746 * *$ \\
\hline SOD & $-3.2933 *$ & $-3.4784 * *$ & $-9.5344 * *$ & $-9.5677 * *$ \\
\hline PCI & $-3.2993 *$ & $-3.8474 *$ & $-7.4893 * *$ & $-7.5987 * *$ \\
\hline HUD & -0.2884 & -1.2994 & $-9.2994 * *$ & $-9.7898 * *$ \\
\hline
\end{tabular}

\subsection{Results of Panel Cointegration Test}

The next test applied with the motive to explore the cointegrated relationships between the variables was panel cointegration test, the results of which have been shown in the table 3. The table contains results about two types of statistics i.e. homogeneous panel and heterogeneous group statistics also called as within dimension and between dimension. As per the table, it is quite clear that three out of four values from within dimension have rejected the null hypothesis of no cointegration and in the same way; all the values from between dimension have rejected the null hypothesis of no cointegration. Overall, it can be stated that six out of the total seven values have rejected the null hypothesis of no cointegration leading towards the conclusion that there are cointegrated relationships between the variables of the study.

Table 3: Cointegration Test - Pedroni Panel

\begin{tabular}{lll}
\hline Test & Statistics & T-values \\
\hline (Within Dimension) & & \\
Panel v-Statistic & $-1.3889^{*}$ & $-6.8666^{*}$ \\
Panel $\rho$-Statistic & $-1.2881^{*}$ & $-5.40888^{*}$ \\
Panel t-Statistic: (non-parametric) & $-1.4666^{*}$ & $-4.8765^{*}$ \\
Panel t-Statistic (adf): (parametric) & -4.1987 & -6.8667
\end{tabular}


JOURNAL OF SECURITY AND SUSTAINABILITY ISSUES

ISSN 2029-7017/ISSN 2029-7025 (online)

2020 Volume 10 Number (October)

http://doi.org/10.9770/jssi.2020.10.Oct(19)

(Between Dimension)

Group $\rho$-Statistic

Group t-Statistic: (non-parametric)

Group t-Statistic (adf): (parametric)

$\begin{array}{ll}-1.6787 * * & -9.2447 * * \\ -0.9779 * & -8.8766^{*} \\ -2.98768^{*} & -8.9776^{*}\end{array}$

\subsection{Results of FMOLS Coefficient Estimation}

The next step was to find out what impact is casted by the independent and control variables on the dependent variable of the study and for this purpose, the researcher had used the FMOLS estimation test, the results of which have been given in the table 4. As per the table, it is clear that environmental regulations have significant and positive impact on environmental sustainability as the $p$ - value is less than 0.05 . This means that with the increase in one percent of environmental regulations, the environmental sustainability will increase by $21.2 \%$. In the same way, the impact of green innovation has positive and significant impact on environmental sustainability and it suggests that with one percent increase in green innovation, the environmental sustainability will be increased by $30.4 \%$. The last independent variable i.e. social distribution is also found to have a positive and significant impact on environmental sustainability and it indicates that with one percent increase in social distribution, the environmental sustainability will be decreased by $29 \%$. In the last, the control variable, per capita income is having positive and significant impact on environmental sustainability. In other words, when the per capita income is increased by one percent, the environmental sustainability will also be increased by $28.8 \%$. In the same way, the other control variable, human development is also having positive and significant impact on environmental sustainability. In other words, when the human development is increased by one percent, the environmental sustainability will also be increased by $12.1 \%$. The value of $\mathrm{R}$ square indicates that $87.1 \%$ change in environmental sustainability is caused by all these variables and the remaining change is caused by some other variables.

Table 4: FMOLS Estimation

\begin{tabular}{llll}
\hline Estimator & Coefficient & Standard Error & Probability \\
\hline ENR & $0.212^{*}$ & 0.288 & 0.000 \\
GRI & $0.304^{*}$ & 0.294 & 0.023 \\
SOD & $0.290^{*}$ & 0.533 & 0.003 \\
PCI & $0.288^{*}$ & 0.398 & 0.028 \\
HUD & $0.121^{*}$ & 0.454 & 0.000 \\
Adj. R Square & $\mathbf{0 . 8 7 1}$ & $\mathbf{0 . 8 8 5}$ & $\mathbf{0 . 0 0 0}$ \\
F-Value & $\mathbf{4 3 . 8 9 4 S}$ & - & - \\
D.W. Stat & $\mathbf{2 . 1 8 8}$ & - & - \\
\hline
\end{tabular}

The results of multicollinearity test applied by the researcher have been presented in table 5. According to these results, it is very clear that the value (1.211) of mean VIF (variance inflation factor) for all the variables is quite close to 1 which shows that there is no issue regarding multicollinearity in these variables.

Table 5: Multicollinearity Test

\begin{tabular}{lll}
\hline & VIF & 1/VIF \\
\hline ENR & 1.493 & .768 \\
GRI & 2.299 & .488 \\
SOD & 1.994 & .885 \\
PCI & 1.454 & .596 \\
HUD & 0.299 & .889 \\
Mean VIF & 1.211 & - \\
\hline
\end{tabular}


JOURNAL OF SECURITY AND SUSTAINABILITY ISSUES

ISSN 2029-7017/ISSN 2029-7025 (online)

2020 Volume 10 Number (October)

http://doi.org/10.9770/jssi.2020.10.Oct(19)

\subsection{Results of Panel Granger Casualty Test}

The results of granger casualty test have been presented in the table 6 in which the variables having unidirectional and bidirectional have been given. It is clear that bidirectional casualty is running between environmental regulations and human development. On the other hand, unidirectional casualty is running from environmental regulations to environmental sustainability, from social distribution to environmental sustainability, from per capita income to green innovation, from environmental regulations to social distribution, from environmental sustainability to per capita income, from environmental sustainability to social distribution and finally from green innovation to human development.

Table 6: Granger Casualty Test

\begin{tabular}{lllllll}
\hline Variables & ENS & ENR & GRI & SOD & PCI & HUD \\
\hline ENS & - & .022 & .122 & .012 & $.122^{*}$ & .122 \\
ENR & $.373 * *$ & - & .033 & $-122^{*}$ & .012 & $.271^{*}$ \\
GRI & .047 & .012 & .012 & .021 & .026 & $.367 *$ \\
SOD & $.035^{*}$ & .037 & $.102 *$ &. & .002 & .036 \\
PCI & .202 & .054 & .010 & .012 & - & .016 \\
HUD & .001 & $.027 *$ & & & - \\
\hline
\end{tabular}

\section{Discussion and Conclusion}

\subsection{Discussion}

With the purpose to find out and investigate the impact of environmental regulations, green innovation and social distribution on the environmental sustainability of ASEAN countries, the researcher came up with three hypotheses which were having the foundation from the past literature. These hypotheses were generated so that they can be tested on the basis of the results obtained by application of various techniques and tests over the collected data. The first hypothesis was that the impact of environmental regulations is significant over the environmental sustainability. This hypothesis was accepted on the basis of the results as the impact of environmental regulations was found as significant. When proper regulation regarding environment are made and implemented as well, it enhances the environmental sustainability of the country and this result is in consistency with the past studies (Shen, Wei, \& Yang, 2017). The next hypothesis was that green innovation has significant impact on environmental sustainability and this hypothesis was also accepted as per the results of the study. With the increase in the production of environment friendly products through environment friendly techniques, the environmental sustainability is ensured. This result has been confirmed with the results obtained from the similar studies from the past (Li et al., 2018). The last hypothesis was that the social distribution has significant impact on the environmental sustainability and this hypothesis was also confirmed on the basis of the results. If the social capital is distributed effectively, the environmental sustainability is ensured. This result is in accordance with the similar past studies (C.-H. Liu, 2017). In addition, two control variables were also taken into consideration i.e. per capita income and human development. The impact of both these control variables over the environmental sustainability has been found as significant which is totally in concordance with the past literature (Kisel'áková, Šofranková, Gombár, Čabinová, \& Onuferová, 2019). Hence it can be stated that all the independent and control variables have significant impact on environmental sustainability. 
JOURNAL OF SECURITY AND SUSTAINABILITY ISSUES

ISSN 2029-7017/ISSN 2029-7025 (online)

2020 Volume 10 Number (October)

http://doi.org/10.9770/jssi.2020.10.Oct(19)

\subsection{Conclusion}

In regard of the objective of the current study i.e. to find out and investigate the impact of environmental regulations, green innovation and social distribution on the environmental sustainability of ASEAN countries, the researcher has collected data from ASEAN countries for 29 years and has applied a number of relevant tests and techniques such as panel unit root test, panel cointegration test, FMOLS coefficient estimation and Granger Casualty test. The results have indicated that all the independent (environmental regulations, green innovation and social distribution) and control variables (per capita income and human development) have significant impact on environmental sustainability. This leads towards the conclusion that the countries must devise proper environmental regulations and must invest in the green and environment friendly innovative projects so that the environmental sustainability can be ensured in these countries.

\subsection{Implications and Limitations}

As far as the practical implications are concerned, the countries can get information and guidance from this study to devise proper environmental regulations and must invest in the green and environment friendly innovative projects so that the environmental sustainability can be ensured in these countries. The policies must be made by the government to enforce these aspects. The theoretical implication is that the researchers will find literature and information about the relevant aspects to be used in their studies for future research.

The sample size of the current study is 29 years, which must be increased, by the other researchers and other new and latest techniques must be used for analysis purpose to get results that are more accurate. In addition, the researchers might also consider various other countries and regions to obtain their perspective as well and to increase the literature on this topic. In this way, the study can be improved academically.

\section{References}

Abdelzaher, D. M., \& Abdelzaher, A. (2017). Beyond environmental regulations: Exploring the potential of “eco-Islam" in boosting environmental ethics within SMEs in Arab markets. Journal of Business Ethics, 145(2), $357-371$. https://link.springer.com/article/10.1007/s10551-015-2833-8

Anbumozhi, V. (2017). Ensuring ASEAN's sustainable and resilient future. Building ASEAN community: Political-security and socio-cultural reflections, 4, 309-323.

Baland, J.-M., Bardhan, P., \& Bowles, S. (2018). Inequality, cooperation, and environmental sustainability: Princeton University Press.

Centobelli, P., Cerchione, R., \& Esposito, E. (2017). Environmental sustainability in the service industry of transportation and logistics service providers: Systematic literature review and research directions. Transportation Research Part D: Transport and Environment, 53, 454-470. https://www.sciencedirect.com/science/article/pii/S1361920916305302

Clayton, S., Kals, E., \& Feygina, I. (2016). Justice and environmental sustainability Handbook of social justice theory and research (pp. 369-386): Springer.

Dalle, J., Hairudinor, Baharuddin, Sriadhi, \& Chandra, T. 2020. Does information technology unrest alter the effect of risk-taking attitude on the organization's performance? Journal of Security and Sustainability Issues, 9(M), $158-172$. https://doi.org/10.9770/jssi.2020.9.M(13)

Dinica, V. (2018). The environmental sustainability of protected area tourism: towards a concession-related theory of regulation. Journal of Sustainable $\quad$ Tourism, $\quad 26(1), \quad 146-164$. https://www.tandfonline.com/doi/abs/10.1080/09669582.2017.1322599

Dumitrescu, E.-I., \& Hurlin, C. (2012). Testing for Granger non-causality in heterogeneous panels. Economic Modelling, 29(4), 1450-1460.

Eddelani, O., El Idrissi, N. E., Monni, S. (2019). Territorialized forms of production in Morocco: provisional assessment for an own model in gestation. Insights into Regional Development, 1(1), 6-18. https://doi.org/10.9770/ird.2019.1.1(1)

Feng, Z., Zeng, B., \& Ming, Q. (2018). Environmental regulation, two-way foreign direct investment, and green innovation efficiency in China's manufacturing industry. International journal of environmental research and public health, 15(10), 2292. https://www.mdpi.com/1660-4601/15/10/2292 


\section{JOURNAL OF SECURITY AND SUSTAINABILITY ISSUES}

ISSN 2029-7017/ISSN 2029-7025 (online)

2020 Volume 10 Number (October)

http://doi.org/10.9770/jssi.2020.10.Oct(19)

Font, X., Garay, L., \& Jones, S. (2016). A social cognitive theory of sustainability empathy. Annals of Tourism Research, 58, 65-80.

Freudenreich, B., Lüdeke-Freund, F., \& Schaltegger, S. (2019). A stakeholder theory perspective on business models: Value creation for sustainability. Journal of Business Ethics, 1-16. https://link.springer.com/article/10.1007\%2Fs10551-019$\underline{04112-z}$

Ghauri, P., Grønhaug, K., \& Strange, R. (2020). Research methods in business studies: Cambridge University Press.

Gliedt, T., Hoicka, C. E., \& Jackson, N. (2018). Innovation intermediaries accelerating environmental sustainability transitions. Journal of Cleaner Production, 174, 1247-1261.

Grabara, J., Hussain, H.I., Szajt, M. (2020) Sustainable University Development through Sustainable HR and Corporate Entrepreneurship: The role of Sustainable Innovation and Environment, Amfiteatru Economic, 22 (54), 480-495. https://www.ceeol.com/search/article-detail?id=851882

Hernández de Velazco, J.J., Ravina Ripoll, R., \& Chumaceiro Hernandez, A.C. (2020). Relevance and social responsibility of sustainable university organizations: analysis from the perspective of endogenous capacities. Entrepreneurship and Sustainability Issues, 7(4), 2967-2977. https://doi.org/10.9770/jesi.2020.7.4(26)

Hummel, K., \& Schlick, C. (2016). The relationship between sustainability performance and sustainability disclosureReconciling voluntary disclosure theory and legitimacy theory. Journal of Accounting and Public Policy, 35(5), 455-476. https://www.sciencedirect.com/science/article/pii/S0278425416300333

Igaliyeva, L., Niyazbekova, Sh., S., Serikova, M., Kenzhegaliyeva, Z., Mussirov, G., Zueva, A., Tyurina, Yu., \& Maisigova, L. (2020). Towards environmental security via energy efficiency: a case study. Entrepreneurship and Sustainability Issues, 7(4), 3488-3499. http://doi.org/10.9770/jesi.2020.7.4(61)

Iqbal, A., Farooqi, M. T. K., \& Ahmed, S. (2020). Endangered Species In Teaching Profession: Perceptions Of Male And Female Prospective Teachers About Teaching Career. Hamdard Islamicus, 43(3), 52-67.

Issock Issock Paul, B., Roberts-Lombard, M., \& Mpinganjira, M. (2020). Understanding household waste separation in South Africa: An empirical study based on an extended theory of interpersonal behaviour. Management of Environmental Quality: An International Journal, 31(3), 530-547. https://www.emerald.com/insight/content/doi/10.1108/MEQ-082019-0181/full/html

Kalton, G. (2020). Introduction to survey sampling (Vol. 35): SAGE Publications, Incorporated.

Khan, S., Maqbool, A., Haleem, A., \& Khan Mohd, I. (2020). Analyzing critical success factors for a successful transition towards circular economy through DANP approach. Management of Environmental Quality: An International Journal, 31(3), 505-529. https://www.emerald.com/insight/content/doi/10.1108/MEQ-09-2019-0191/full/html

Kheng-Lian, K., Robinson, N. A., \& Lin-Heng, L. (2016). ASEAN Environmental Legal Integration: Sustainable Goals? (Vol. 13): Cambridge University Press.

Kanwal, N., Khan, M., \& Kanwal, N. (2020). Mixed Methods Analysis Of Factors Influencing Self-Efficacy In StudentTeachers During Teaching Practices. Hamdard Islamicus, 43(3), 68-82.

Kiseláková, D., Šofranková, B., Gombár, M., Čabinová, V., \& Onuferová, E. (2019). Competitiveness and Its Impact on Sustainability, Business Environment, and Human Development of EU (28) Countries in terms of Global MultiCriteria Indices. Sustainability, 11(12), 3365. https://www.mdpi.com/2071-1050/11/12/3365

Levin, A., \& Lin, C.-F. (1993). Unit root tests in panel data: new results. University of California at San Diego, Economics Working Paper Series.

Luo, Z., \& Wu, D. (2020). Effects of social security factors on mental health of rural-to-urban migrant workers. Revista Argentina de Clinica Psicologica, 29(1), 71-76. https://doi.org/10.24205/03276716.2020.10

Levin, A., Lin, C.-F., \& Chu, C.-S. J. (2002). Unit root tests in panel data: asymptotic and finite-sample properties. Journal of econometrics, 108(1), 1-24. https://www.sciencedirect.com/science/article/abs/pii/s0304407601000987

Li, D., Huang, M., Ren, S., Chen, X., \& Ning, L. (2018). Environmental legitimacy, green innovation, and corporate carbon disclosure: Evidence from CDP China 100. Journal of Business Ethics, 150(4), 1089-1104. https://link.springer.com/article/10.1007/s10551-016-3187-6

Liu, C.-H. (2017). The relationships among intellectual capital, social capital, and performance-The moderating role of business ties and environmental uncertainty. Tourism management, 61, 553-561.

Liu, X., Zhang, S., \& Bae, J. (2017). The impact of renewable energy and agriculture on carbon dioxide emissions: investigating the environmental Kuznets curve in four selected ASEAN countries. Journal of Cleaner Production, 164, 1239-1247. https://www.sciencedirect.com/science/article/abs/pii/S0959652617315147.

Mahrinasari, M., Haseeb, M., \& Ammar, J. (2019). Is trade liberalization a hazard to sustainable environment?: fresh insight from ASEAN countries. Polish Journal of Management Studies, 19. 


\section{JOURNAL OF SECURITY AND SUSTAINABILITY ISSUES}

ISSN 2029-7017/ISSN 2029-7025 (online)

2020 Volume 10 Number (October)

http://doi.org/10.9770/jssi.2020.10.Oct(19)

Mei, Y., Kang, S., Lv, Q., \& Yan, X. (2020). Mental health of tour guides from the perspective of burnout. Revista Argentina de Clinica Psicologica, 29(1), 84-89. https://doi.org/10.24205/03276716.2020.12

Mikhaylov, A., Moiseev, N., Aleshin, K., \& Burkhardt, T. (2020). Global climate change and greenhouse effect. Entrepreneurship and Sustainability Issues, 7(4), 2897-2913. http://doi.org/10.9770/jesi.2020.7.4(21)

Moumen, Z., El Idrissi, N.E.A., Tvaronavičienè, M., Lahrach, A. (2019). Water security and sustainable development. Insights into Regional Development, 1(4), 301-317. https://doi.org/10.9770/ird.2019.1.4(2)

Niesten, E., Jolink, A., de Sousa Jabbour, A. B. L., Chappin, M., \& Lozano, R. (2017). Sustainable collaboration: The impact of governance and institutions on sustainable performance. Journal of Cleaner Production, 155, 1-6. https://www.sciencedirect.com/science/article/abs/pii/s0959652616321527

Nuryakin, \& Maryati, T. (2020). Green product competitiveness and green product success. Why and how does mediating affect green innovation performance? Entrepreneurship and Sustainability Issues, 7(4), 3061-3077. https://doi.org/10.9770/jesi.2020.7.4(33)

Pedroni, P. (1999). Critical values for cointegration tests in heterogeneous panels with multiple regressors. Oxford Bulletin of Economics and statistics, 61(S1), 653-670.

Pedroni, P. (2000). Fully modified OLS for heterogeneous cointegrated panels. Advances in econometrics, 15, 93-130.

Pedroni, P. (2001). Fully modified OLS for heterogeneous cointegrated panels Nonstationary panels, panel cointegration, and dynamic panels (pp. 93-130): Emerald Group Publishing Limited.

Pérez-Rincón, M., Vargas-Morales, J., \& Crespo-Marín, Z. (2018). Trends in social metabolism and environmental conflicts in four Andean countries from 1970 to 2013. Sustainability science, 13(3), 635-648. https://link.springer.com/article/10.1007/s11625-017-0510-9

Piyathanavong, V., Garza-Reyes, J. A., Kumar, V., Maldonado-Guzmán, G., \& Mangla, S. K. (2019). The adoption of operational environmental sustainability approaches in the Thai manufacturing sector. Journal of Cleaner Production, 220, 507-528.

Prasetyo, P.E., \& Kistanti, N.R. (2020). Human capital, institutional economics and entrepreneurship as a driver for quality \& sustainable economic growth. Entrepreneurship and Sustainability Issues, 7(4), 2575-2589. https://doi.org/10.9770/jesi.2020.7.4(1)

Planas, A., Reig, F., Palmi, J., Del Arco, I., \& Prat, J. A. (2020). Motivations, barriers and physical condition in adolescents, according to the stage of change in physical exercise. Revista de Psicologia del Deporte, 29(2), 125-134.

Ramanathan, R., He, Q., Black, A., Ghobadian, A., \& Gallear, D. (2017). Environmental regulations, innovation and firm performance: A revisit of the Porter hypothesis. Journal of Cleaner Production, 155, 79-92. https://www.sciencedirect.com/science/article/abs/pii/s0959652616312641

Rosen, M. A. (2018). Environmental sustainability tools in the biofuel industry. Biofuel Research Journal, 5(1), 751-752. https://www.biofueljournal.com/article 58093.html

Saunila, M., Ukko, J., \& Rantala, T. (2018). Sustainability as a driver of green innovation investment and exploitation. Journal of Cleaner Production, 179, 631-641.

Scheidel, A., Temper, L., Demaria, F., \& Martínez-Alier, J. (2018). Ecological distribution conflicts as forces for sustainability: an overview and conceptual framework. Sustainability science, 13(3), 585-598. https://link.springer.com/article/10.1007/s11625-017-0519-0

Schröter, M., Stumpf, K. H., Loos, J., van Oudenhoven, A. P., Böhnke-Henrichs, A., \& Abson, D. J. (2017). Refocusing ecosystem services towards sustainability. Ecosystem services, 25, 35-43.

Seidel, S., Chandra Kruse, L., Székely, N., Gau, M., \& Stieger, D. (2018). Design principles for sensemaking support systems in environmental sustainability transformations. European Journal of Information Systems, 27(2), 221-247. https://www.tandfonline.com/doi/full/10.1057/s41303-017-0039-0

Shen, J., Wei, Y. D., \& Yang, Z. (2017). The impact of environmental regulations on the location of pollution-intensive industries in China. Journal of Cleaner Production, 148, 785-794.

Song, W., \& Yu, H. (2018). Green innovation strategy and green innovation: The roles of green creativity and green organizational identity. Corporate Social Responsibility and Environmental Management, 25(2), 135-150.

Stern, M. J. (2018). Social science theory for environmental sustainability: A practical guide: Oxford University Press.

Sukcharoensin, S. (2018). Strategic Position of Bond Markets in ASEAN-5: Challenges and Directions for Development. DLSU Business \& Economics Review, 27(2), 23-34.

Suki, N. M., Sharif, A., Afshan, S., \& Suki, N. M. (2020). Revisiting the Environmental Kuznets Curve in Malaysia: The role of globalization in sustainable environment. Journal of Cleaner Production, 121669. 
JOURNAL OF SECURITY AND SUSTAINABILITY ISSUES

ISSN 2029-7017/ISSN 2029-7025 (online)

2020 Volume 10 Number (October)

http://doi.org/10.9770/jssi.2020.10.Oct(19)

Tang, M., Walsh, G., Lerner, D., Fitza, M. A., \& Li, Q. (2018). Green innovation, managerial concern and firm performance: An empirical study. Business Strategy and the Environment, 27(1), 39-51.

Temper, L., Demaria, F., Scheidel, A., Del Bene, D., \& Martinez-Alier, J. (2018). The Global Environmental Justice Atlas (EJAtlas): ecological distribution conflicts as forces for sustainability. Sustainability science, 13(3), 573-584. https://link.springer.com/article/10.1007/s11625-018-0563-4

Tvaronavičienè, M., \& Ślusarczyk, B. (2019). Energy transformation towards sustainability. Energy transformation towards sustainability (pp. 1-333) https://doi.org/10.1016/C2018-0-02510-4

Valencia, G. A. D., Norato, O. M. G., Paéz, A. A. V., \& Romero, R. (2020). Formas de financiación informal de los comerciantes informales en Colombia Casos: Cúcuta, Ibagué y Villavicencio. Cuadernos de Economía, 43(123). https://doi.org/10.32826/cude.v43i123.126

van Huis, A., \& Oonincx, D. G. (2017). The environmental sustainability of insects as food and feed. A review. Agronomy for Sustainable Development, 37(5), 43.

Vincenzi, S. L., Possan, E., de Andrade, D. F., Pituco, M. M., de Oliveira Santos, T., \& Jasse, E. P. (2018). Assessment of environmental sustainability perception through item response theory: A case study in Brazil. Journal of Cleaner Production, 170, 1369-1386. https://www.sciencedirect.com/science/article/abs/pii/s0959652617322205

Yonn, R. (2017). The effects of Cambodia economy on ASEAN economic moving forward. Journal of Management, Economics, and Industrial Organization, 1(2), 1-16.

Ichsan ANWARY

ORCID ID: https://orcid.org/0000-0002-4693-6467

Yahya Ahmad ZEIN

ORCID ID: https://orcid.org/0000-0002-8686-2458

Register for an ORCID ID:

https://orcid.org/register

This work is licensed under the Creative Commons Attribution International License (CC BY). http://creativecommons.org/licenses/by/4.0/

(c) (†) Open Access 